\title{
Doğu ve Güneydoğu Anadolu Bölgelerinden Göçle Gelen Ergenlerde Benlik Saygısını Yükseltme Programının Etkililiğinin Araştırılması
}

\section{The Efficacy of Self-Esteem Promotion Program on the Adolescents Migrated From East and Southeastern Anatolia Regions}

\author{
(Araştırma) \\ Zeliha KAYA ERTEN*, Ümit SEViĞ**
}

öz

\begin{abstract}
Amaç: Bu çalışma Sister Callista Roy'un uyum modelinden yola çıkılarak göçle gelen ve gelmeyen ergenlerin uyumlarını artırmak için yapılan benlik saygısını yükseltme programının benlik saygısı düzeyine etkisini belirlemek amacıyla yarı deneysel olarak yapılmıștır.
\end{abstract}

Gereç ve Yöntem: Kayseri’ye 5-8 yıl içinde göçle gelmiş ve Kayseri'de yaşayan 13-14 yaş grubu ergenler çalışma kapsamına alınmıştır. Göçle gelen ve gelmemiş olan 40 ergenden oluşan 2 müdahale 2 kontrol olmak üzere 4 grup oluşturulmuștur. Müdahale gruplarına ayrı ayrı benlik saygısı yükseltme programı uygulanmıștır. Kontrol gruplarına herhangi bir program uygulanmamıştır. Sosyo-demografik özelliklerin ve benlik saygısını etkileyen faktörlerin belirlenebilmesi için "Kişisel Bilgi Formu"; benlik saygısı düzeylerini belirlemek için "Lise Öğrencileri Özsaygı (Benlik Saygısı) Envanteri” kullanılmıștır. Bütün grupların benlik saygı düzeyleri, ön test, son test ve izlem ölçümleri ile değerlendirilmiştir.

Bulgular: Benlik saygısı yükseltme programı sonrası müdahale gruplarının benlik saygısı puan ortalamaları, kontrol gruplarının puan ortalamalarından istatistiksel olarak anlamlı şekilde daha yüksek bulunmuştur. Göçle gelen ve gelmeyen müdahale grupları arasında puan farkları ortalamaları arasında istatistiksel olarak anlamlı bir fark bulunmamıștır.

Sonuç: Çalışmada sosyo ekonomik ve kültürel ortamın bireylerin uyumunu göç kadar etkilediği düşünülürken, benlik saygısı yükseltme programının ise aynı ortamı paylaşan göçle

\footnotetext{
*Nuh Naci Yazgan Üniversitesi, Sağlık Bilimleri Fakültesi Hemşirelik ve Sağlık Hizmetleri Bölümü, Kayseri, Türkiye, E-mail: kayazkaya@gmail.com, Tel. 035232400 00, ORCID: https://orcid.org/0000-0003-1229-7350

**Erciyes Üniversitesi, Sağlık Bilimleri Fakültesi Hemşirelik Bölümü, Kayseri, Türkiye,

E-mail: usevig@erciyes.edu.tr, Tel.0 35220766 66, ORCID: https://orcid.org/0000-0002-3518-6648

Geliş Tarihi: 24 Ocak 2018, Kabul Tarihi: 25 Mayıs 2018
}

Bu makale 2-6 Ekim 2012 tarihleri arasında Bursa da gerçekleştirilen 15. Ulusal Halk Sağlığı Kongresinde poster bildiri olarak sunulmuştur.

Atıf/Citatian: Kaya Erten Z., Seviğ Ü. Doğu ve Güneydoğu Anadolu Bölgelerinden Göçle Gelen Ergenlerde Benlik Saygısını Yükseltme Programının Etkililiğinin Araştırılması. Hacettepe Üniversitesi Hemşirelik Fakültesi Dergisi 2018; 5(2):... https://doi.org/ 
gelen ve gelmeyen ergenlerin benlik saygılarını kontrol gruplarına göre ve kendi ön-son test puan ortalamalarına göre olumlu ve benzer şekilde etkilediği bulunmuștur.

Anahtar Kelimeler: Adölesan, benlik saygısı, göç, halk sağlı̆̆l, hemşirelik,

\section{ABSTRACT}

Aim: This study was conducted as a quasi-experimental study to determine the effect of selfesteem promotion program that developed by using Sister Callista Roy's adaptation model to increase adaptation of immigrant and nonimmigrant adolescents on their self-esteem levels.

Material and Methods: Adolescents, aged between 13 to 14, who migrated to Kayseri in 5-8 years and live in Kayseri were included in the study. Four groups including two intervention and two control groups were formed. The groups consisted of total 40 immigrant and nonimmigrant adolescents. The self-esteem promotion program was applied separately to two intervention groups. No intervention was applied to the control groups. The sociodemographic characteristics of the groups and the factors affecting their self-esteem were determined through a questionnaire. Self-esteem levels were determined by using "High School Students' Self-Esteem Inventory" by pre-test, post-test and follow-up measurements.

Results: After self-esteem promotion program, it was found that the mean score of selfesteem was statistically higher in the intervention groups than control groups. There was no significant difference between the mean score of immigrant and nonimmigrant intervention groups.

Conclusion: It is concluded that socio-economic and cultural environment could affect the adaptation of people as much as migration. However, it was found that the self-esteem promotion program had an effect on self-esteem of both immigrant and nonimmigrant adolescents in the intervention groups who share the same environment according to their own pre and post-test mean scores and control groups positively and similarly.

Key Words: Adolescent, migration, nursing, public health, self-esteem

\section{GiRiş}

Birey varlığının devamı için biyolojik, fiziksel ve sosyal bir çevreye ihtiyaç duyar ve sürekli bu çevre ile karşılıklı etkileşim içindedir. Çevre bireyin algılamasını, davranışlarını, büyüme ve gelişmesini etkileyen kültürel, gelişimsel ve psikososyal durumları içerir. Bireyin çevresinde olacak herhangi bir değişim bireyin sağlığını olumlu ya da olumsuz olarak etkiler. Günümüzde bireylerin çevrelerini değiştirmelerine neden olacak en önemli unsurlardan biri göçtür. Göç, sosyal yapı içindeki bireyin veya grupların ekonomik, kültürel, güvenlik ya da siyasi nedenlerden dolayı bir bölgeden başka bir bölgeye yer değiştirmesidir ${ }^{1}$. Göç, ilk bakışta basit bir çevre değiştirme süreci gibi görünse de sonuçları bakımından toplum ve birey üzerindeki etkisi büyüktür. Göç ile insanlar çevrelerini tamamen değiştirdikleri için yeni çevrelerine uyum sağlayana kadar birçok sorunla karşı karşıya kalabilirler ${ }^{2-4}$.

Gönüllü göçler genellikle ekonomik nedenlerden olurken, zorunlu göçler güvenlik ve siyasi nedenlerden kaynaklanmaktadır ${ }^{5}$. Göçler ister zorunlu ister gönüllü, ister kısa isterse uzun dönemli olsun bu hareketin temel unsuru insandır. Göçün gönüllü olması yetişkinler için bilinçli bir eylemdir. Göç kararı yetişkinler tarafından alındığından çocuk ve ergenler açısından her zaman zorunludur. Göç yaşantısında çevresel ve sosyal değişim genellikle anidir. Bu nedenle bireylerin uyum süreci bu değişimden olumsuz yönde etkilenmektedir. Roy'un uyum modeli bir etkileşim modelidir ve insan-çevre arasındaki etkileşime odaklanır ${ }^{6}$. Bir hemşirelik kuramcısı olan Roy hemşirenin 
bireylere bakım verirken bireylerin hastalıkları (fiziksel, sosyal, psikolojik) nedeni ile değişen durumlarına uyum sağlamalarının önemli olduğunu belirtmiş, kuramını bireylerin yeni durumlarına uyumları üzerine kurmuştur. Roy bütün bireylerin 4 farkl gereksinimi olduğunu belirtmiştir. Bunlar: temel fizyolojik gereksinimler, olumlu benlik kavramı, sosyal rol, bağımlılık ve bağımsızlığın dengelenmesidir. Uyumun sağlanması için bu dört alanda bireylerin desteklenmesi gerekliliği üzerinde durmaktadır ${ }^{7-10}$. Göç olgusunda sağlığın devamı için göçmenlerin uyumlarının sağlanması gerekmektedir. Özellikle çocuk ve ergenler göçle beraber aynı anda fiziksel ve ruhsal büyüme ile de baş etmek zorunda olduklarından göçün negatif etkilerini yetişkinlere göre daha yoğun yaşamaktadırlar. Gelişim dönemleri arasında ergenlik, olumlu benlik kavramının gelişmesi adına önemli bir dönemdir. Freud ve Erikson gibi gelişim psikologları çocuğun doğumundan itibaren gelișen benliğin özellikle okul döneminde pekiștirildiğini ifade ederler ${ }^{11,12}$. Erikson, 5. dönem (12-18 yaş) olarak tarif ettiği okul döneminde ergenlerin cinsel, toplumsal ve mesleksel yönleri ile benliğinin oluştuğunu belirtir ${ }^{12}$. Bu dönemde çocukların çevre ve kendilerine ilişkin olan uyum sorunları diğer dönemlere göre daha fazladır ${ }^{13,14}$. Göçle gelen çocuk ve ergenlerde en sık rastlanan sorunlarının davranış bozukluğu, kimlik karmaşası, düșük benlik saygısı, kaygı bozukluğu, depresyon, somatik bozukluklar, çift dillilikten kaynaklanan sorunlar, enürezis, düşük akademik başarı ve kuşak çatışması olduğu belirtilmektedir. Yine yapılan çalışmalarda ${ }^{15,16}$ iç göç yaşayan ergenlerde dil sorunu olmasa bile ruhsal belirti şiddetinin yüksek olduğu, aynı şekilde göçle gelen yetişkinlerin de yaklaşık 2/3'sinin travma yaşadığı bulunmuştur. Göç sonrası travma yaşayan bir grupla yapılan çalışma bulguları zorunlu göç mağdurlarının işkence mağdurlarına benzer düzeyde bir stres bozukluğu yaşadıklarını göstermektediir ${ }^{16-17}$. Diğer yandan, göçün sokak çocukları, sokakta çalışan çocuklar ve çocuk suçluluğu gibi durumlara sebep olduğu belirtilmektedir ${ }^{7,18}$. Özellikle Doğu ve Güneydoğu'dan göçle gelen çocuklarla yapılan bir çalışmada ${ }^{18}$, çocukların benlik saygılarının, kültürlenme düzeylerinin, sosyal desteklerinin ve kişisel yaşam doyumlarının göç deneyimi yaşamamış çocuklara göre düşük olduğunu göstermektedir. Bu çalışma Kayseri'ye göçle gelen ve Kayseri'de doğmuş büyümüş ergenlerin benlik saygısını yükseltmeye yönelik yapılacak grup rehberliğinin, benlik saygısı düzeyine etkisini belirlemek ve hemşirelik literatürüne benlik saygısı yükseltme programını bir yöntem olarak katmayı amaçlamıştır. Çalışmanın birinci basamakta çalışan hemşirelere, riskli gruplarda bu tür çalışmalara yer vermelerine ilişkin yol gösterici olacağı düşünülmektedir.

\section{GEREÇ ve YÖNTEM}

Araştırma göçle gelen ve gelmeyen ergenlerde benlik saygısı düzeyinin belirlenmesi, göçle gelen ve gelmeyen ergenlere uygulanan benlik saygısını yükseltme programının, benlik saygısını yükseltmeye etkisini belirlemek amacı ile yarı deneysel olarak yapılmıştır.

\section{Araştırmanın Evreni}

Araştırma Kayseri, Eskişehir Bağları Selçuklu mahallesinde yapılmıştır. Eskişehir Bağları diğer göç alan bölgelere göre Doğu ve Güneydoğu Anadolu bölgelerinden daha fazla göç alması, ailelerin sosyo ekonomik düzeylerinin daha düşük olması nedeni ile tercih edilmiştir ${ }^{19}$. Araştırmanın evrenini; Eskişehir Bağları Selçuklu mahallesinde yaşayan Doğu ve Güneydoğu Anadolu bölgesinden 5-8 yil içinde göçle gelmiş 13-14 yaş grubu ergenler oluşturmuştur. 


\section{Araştırmanın Örneklemi}

Benlik saygısı yükseltme programı bir grup rehberliği anlayışı ile yapılmıştır. Literatürde grup dinamiğinin sağlanabilmesi için grup sayısının 6-12 kişi arasında olması gerektiği vurgulanmaktadır ${ }^{20,21}$. Daha önce benzer benlik saygısı yükseltme programı uygulanarak yapılan araştırmalarda, deney ve kontrol gruplarının 6-12 kişiden oluşması nedeni ile ${ }^{22,23}$ bu çalışmada gruplar 10-12 kişi olarak planlanmıştır. İki kontrol (Göçle gelen ve göçle gelmeyen) iki müdahale (Göçle gelen ve göçle gelmeyen) olmak üzere 4 grup oluşturulmuştur. Araştırmada, örnekleme alınacak bireylere ilişkin resmi kayıtların yeterli olmamasından dolayı örneklem grubuna bölgedeki evler gezilerek kartopu örnekleme yöntemi ile ulaşılmıştır. Kontrol ve müdahale gruplarının ortak özellikleri Eskişehir Bağları Selçuklu mahallesinde oturmaları, 13-14 yaş grubunda olmalarıdır. Bunun dışında gruplar arasındaki tek fark göç olgusudur, göçle gelen grup 5-8 yıl içinde Kayseri’ye Güneydoğu ve Doğu Anadolu bölgesinden göç etmiştir.

\section{Araştırmanın Sınırlılıkları}

Mahallede gençlik merkezine 500 metreden uzak evlerde yaşayan ergenlerin ailelerinden izin alınamaması örnekleme ulaşmayı zorlaştırmıştır.

\section{Veri Toplama Aracı}

Araştırmada kişisel bilgi formu ve Öz Saygısı Envanteri olmak üzere iki veri toplama aracı kullanılmıştır. Kişisel bilgi formu araştırmacı tarafından literatür taranarak benlik saygısını etkileyecek unsurlar göze alınarak oluşturulmuştur ${ }^{13,24-26}$. Form demografik özellikler ve benlik saygısını etkileyen faktörlerin belirlendiği toplam 30 sorudan oluşmaktadır. Diğer araç ise Güngör ${ }^{27}$ tarafından geliştirilen Lise Öğrencileri Özsaygı Envanteridir. Envanter Rosenberg ${ }^{28}$ ve Coopersmith ${ }^{29}$ araçlarından bazı ifadeler alınarak oluşturulmuştur.

Envanter 75 maddeden oluşmaktadır. Orijinal envanterde puanlama çift yönlü olup bazı maddelerde "bana benziyor", bazılarında ise "bana benzemiyor" yanıtlarına bir (1) puan verilmektedir. Kaya ve Saçkes ${ }^{30}$ tarafından envanterin yanıtlama biçimi revize edilmiştir. Bu şekilde envanterdeki maddelere verilen yanıtlar "bana benziyor" ve "bana benzemiyor" biçiminden sırası ile "bana tamamen benziyor", "bana çok benziyor", "bana biraz benziyor", "bana çok az benziyor" ve "bana hiç benzemiyor” biçiminde yeniden düzenlenmiştir. Araştırmada en yüksek alınacak puan 375 en düşük alınacak puan ise 75 'tir. Ergenlerin aldığ 1 puanlar 375’e yaklaştıkça benlik saygısı artmakta, 75'e yaklaştıkça benlik saygıları düşmektedir. Envanterin Güngör tarafından yapılan geçerlik çalışmasında, ölçeğin Cronbach a değeri 0.82 bulunmuştur ${ }^{27}$. Bu çalışmada ise ön test Cronbach a değeri 0,84, son test Cronbach a değeri ise 0,71 bulunmuştur.

\section{Araştırmanın Değişkenleri}

Bağımsız Değişken: Göç gelmek, benlik saygısı eğitimi almak, sosyo demografik özellikler.

Bağımlı Değişken: Benlik saygısı düzeyi. 


\section{Araştırmanın Ön uygulaması}

Ön uygulama Mayıs-Haziran 2009 tarihinde yapılmıştır. Uygulama Nuh Mehmet Baldöktü Anadolu Lisesi'nde lise I. sınıfa giden 10 öğrenci ile gerçekleştirilmiştir. Ön uygulamada araştırmacının programı uygulama konusundaki yetkinliği artırılmış ve kişisel bilgi formundaki öğrencinin soruyu anlamasına ilişkin ifadelerdeki aksaklıklar giderilmiştir.

\section{Verilerin Toplanması ve Akıș Şeması}

-Eylül 2010 Seçim kriterlerine uyan ergenler müdahale ve kontrol grubuna alındı.

\section{Seçim Kriterleri}

1. 13-14 yaş grubunda olmak,

2. Göçle gelen deney ve kontrol grubu için Doğu ve Güneydoğu Anadolu bölgelerinden göçle gelmiş olmak,

3. Göçle gelen deney ve kontrol grubu için 5-8 yıl içinde göçle gelmiş olmak,

4. Herhangi bir kronik hastalığa sahip olmamak,

5. Beden kitle indeksi normal sınırlarda olmak,

Ekim 2010'da

- Deney ve kontrol grubundaki ergenlerin kendileri ve ailelerinden yazılı ve sözlü onam alındı.

- Deney ve kontrol grubuna, ergenlerin ve ailesinin tanıtıcı özellikleri, benlik saygısını etkileyen faktörler ve ön test olarak benlik saygısı ölçeği uygulandı.
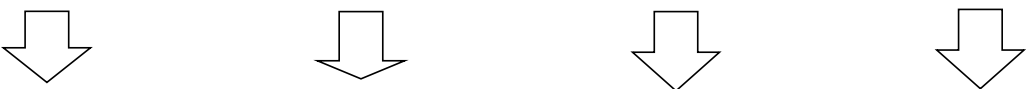

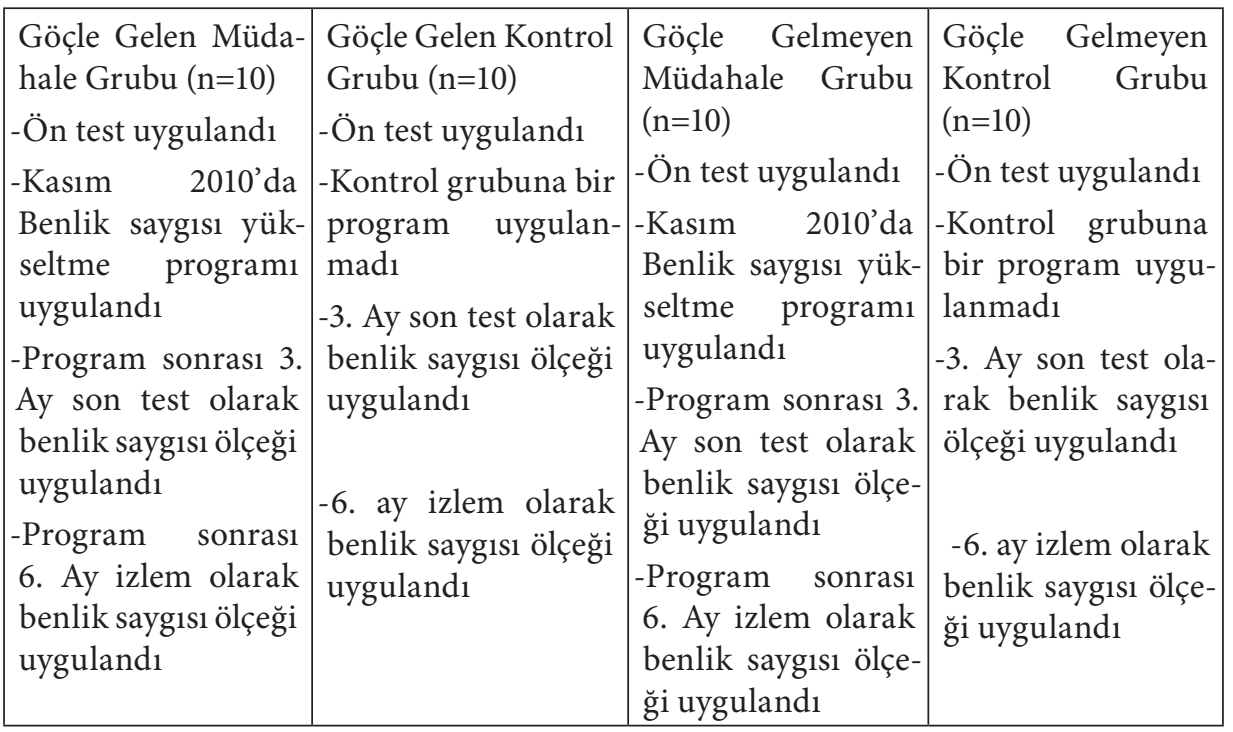




\section{Benlik Saygısı Yükseltme Programı ve Uygulanması}

Uygulama Kayseri Eskişehir bağları Selçuklu mahallesinde bulunan gençlik merkezinin bir salonunda belediyenin yazılı izni ile gerçekleştirilmiştir. Ergenler kendi derslerinin bitiminin ardından merkeze gelmiş ve oturumlar gerçekleştirilmiştir. Oturumlar sırasında ergenlerin kişisel ihtiyaçlarını giderecek ortam araştırmacı tarafından sağlanmıștır.

Uygulanan benlik saygısı yükseltme programı 8 oturumdan oluşmuştur. Her oturum yaklaşık bir saat sürmüş ve haftada bir kez yapılmıştır.

Benlik Saygısı Yükseltme Programının Amacı;

1. Ergenlerin, kendileri hakkında ne hissettiklerini keşfetmelerine ve bu hislerinin nereden kaynaklandığını anlamalarına yardımcı olma.

2. Ergenlerin, hayatlarındaki bazı rolleri tanımlamasına ve bu roller içindeki performanslarının farklı olduğunu görmelerine yardımcı olma.

3. Ergenlerin bir öğrenen, bir arkadaş ve bir kişi olarak kendilerine yönelik algılarının farkına varmalarına yardımcı olma.

4. Ergenlerin kendileri hakkındaki gerçek dışı ve mükemmeliyetçi taleplerini terk etmelerine yardimci olma.

5. Ergenleri, grup içinde kendilerine ilişkin çalışmaları esnasında diğer grup üyelerine de yardım etmek için cesaretlendirme ve ergenlere aynı tür yardımlara nasıl ulaşabileceğini öğretmektir ${ }^{18-26}$.

\section{Araştırmanın Etik Yönü}

Araştırma T.C. Sağlık Bakanlığı ve Erciyes Üniversitesi Sağlık Eğitim ve Araştırma Bölgesinde olan Eskişehir Bağları Selçuklu Mahallesinde yapılmıştır. Protokol gereği Sağlık Bakanlığıve Erciyes Üniversitesi arasında bu bölgede yapılan çalıșmalar için Sağlık Bakanlığından tekrar izin alınmamaktadır. Araştırma öncesi Erciyes Üniversitesi Sağlık Bilimleri Fakültesinden Akademik Kurul kararı (15.5.2009/2009.5/05) alınmış, Erciyes Üniversitesi Etik Kurulundan Etik Kurul izni alınmıştır (B.30.2.ERC.0.20.00.00.18). Araştırmanın Eskişehir Bağları Selçuklu Mahallesinde yapılmasına ve Gençlik Merkezinin kullanımına ilişkin Melikgazi Belediyesi'nden izin alınmıștır. Araştırma kapsamına alınan ergenlerin aile ve kendilerinden bilgilendirilmiş onam formu ile yazılı ve sözlü onamları alınmıştır. Çalışmada benlik saygısını yükseltme programını oluşturan öğretim üyesi Doç. Dr. Alim Kaya'dan programın kullanımına ve beşli likert olarak hazırlanmış benlik saygısı envanteri kullanımına ilişkin sözlü izin alınmıştır.

\section{Verilerin Analizi}

Araştırmadan elde edilen verilerin analizi bilgisayardaSPSS 15.0 ile sigmaStat 3.5 istatistik paket programlarıyla değerlendirilmiștir. Verilerin normal dağılımına Shapiro-Wilk testi ile bakılmıștır. Normal dağılan bağımsız iki grubun karşılaştırılmasında bağımsız iki örnek t testi, kullanılmıştır. Benlik saygısı envanterinin tek gruptaki tekrarlı ölçümlerinde SigmaStat programında One-Way Anavo testi kullanılmıştır. Benlik saygısı envanterinin değerlendirilmesinde Cronbach a değerleri verilmiştir. Kategorik değişkenlerin karşılaştırılmasında ki kare $\left(\chi^{2)}\right.$ testi exact değerlerinden yararlanılmıştır. Karşılaştırmalarda $\mathrm{p}<0.05$ istatistiksel olarak anlamlı olarak kabul edilmiştir. 


\section{BULGULAR}

Tablo 1. Göçle Gelen ve Gelmeyen Ergenlerin Sosyo-Demografik Özellikleri

\begin{tabular}{|c|c|c|}
\hline Sosyo-Demografik Özellikler $(n=40)$ & $\mathbf{n}$ & $\%$ \\
\hline \multicolumn{3}{|l|}{ Yaş } \\
\hline 14 yaş & 34 & 85.0 \\
\hline 13 yaş & 6 & 15.0 \\
\hline \multicolumn{3}{|l|}{ Cinsiyet } \\
\hline Kadın & 18 & 45.0 \\
\hline Erkek & 22 & 55.0 \\
\hline \multicolumn{3}{|l|}{ Kardeş Sayısı } \\
\hline $0-2$ & 10 & 25.0 \\
\hline 3-5 & 21 & 52.5 \\
\hline 6 ve üzeri & 9 & 22.5 \\
\hline \multicolumn{3}{|c|}{ Ergenlerin İfadelerine Göre Gelir Durumu } \\
\hline Gelir Giderden Düşük & 21 & 52.5 \\
\hline Gelir Gidere Denk & 19 & 47.5 \\
\hline \multicolumn{3}{|l|}{ Baba İş } \\
\hline Ne iş yaptığı bilinmiyor & 6 & 15.0 \\
\hline Çalışmıyor & 19 & 47.5 \\
\hline Mevsimlik (inşaat) işçi & 15 & 37.5 \\
\hline \multicolumn{3}{|l|}{ Anne ìş } \\
\hline Ev hanımı & 39 & 97.5 \\
\hline Fabrikada işçi & 1 & 2.5 \\
\hline \multicolumn{3}{|l|}{ Aile Tipi } \\
\hline Çekirdek & 29 & 72.5 \\
\hline Geniş & 11 & 27.5 \\
\hline \multicolumn{3}{|l|}{ Anne Eğitim } \\
\hline Okur-yazar değil & 12 & 30.0 \\
\hline Okur-yazar & 15 & 37.5 \\
\hline İlkokul & 11 & 27.5 \\
\hline Ortaokul & 2 & 5.0 \\
\hline \multicolumn{3}{|l|}{ Baba Eğitim } \\
\hline Okur-yazar & 8 & 20.0 \\
\hline Illkokul & 29 & 72.5 \\
\hline Ortaokul & 3 & 7.5 \\
\hline
\end{tabular}


Araştırma kapsamına alınan ergenlerin tamamı 13-14 yaşlarında. \%45’i kız, \%55’i erkektir. \%52.5’i 3-5 kardeşe sahiptir. Ergenlerin \%52.5’i kendini düşük gelirli tarif ederken \%47.5'i gelir durumunu orta düzeyde olduğunu belirtmiştir. \%47.5’inin babası hiç çalışmazken geriye kalan \%52.5'ide düzenli bir işe sahip değildir. Annelerin tamama yakını ev hanımıdır. Ergenlerin ailelerinin \%72.5'i çekirdek aile yapısına sahiptir. Ergenlerin annelerinin eğitim düzeyleri incelendiğinde \%30'unun okuryazar olmadığı, \%65'inin ise okuryazar ve ilkokul mezunu olduğu belirlenmiştir. Çalışmada babaların tamamına yakının okuryazar ve ilkokul muzunu olduğu tespit edilmiştir.

Ergenlerin benlik saygılarını etkileyebilecek faktörler incelendiğinde \%67.5’i okul başarısını iyi düzeyde nitelendirirken, \%32.5’i okul başarısını orta ve düşük düzeyde görmektedir. Okuldan memnuniyet sorulduğunda ergenlerin \%75.5'i okul hayatından memnun olduğunu bildirmişlerdir. \%52.5' i sağlık durumunu iyi olarak ifade etmişlerdir. Yine benlik saygısını etkileyecek faktörlerden olan anne baba tutumu konusunda da ergenlerin \%70.0'ının annesi çocuklarına sormadan ergenle ilgili kararları kendileri alırken, \%5.0'ı hiç ilgilenmemiştir. Ergenlerin \%57.5'inin babası ergene sormadan kararları kendileri alırken \%12.5'i hiç ilgilenmemiştir. Benlik saygısını etkileyen unsurlardan biri olan beden kitle konusunda öğrencilerin tamamı normal sınırdadırlar.

Araştırma kapsamına alınan deney ve kontrol gruplarının Tablo 1 ve Tablo 2 de yer alan demografik ve benlik saygısını etkileyen faktörler ile ilgili veriler karşılaştırılmıştır. Yapılan analizde gruplar arasında istatistiksel açıdan anlamlı bir fark olmadığ 1 ve grupların hemojenize olduğu görülmüştür ( $\mathrm{p}>0.05)$.

Tablo 3a' da göçle gelen ve gelmeyen ergenlerin benlik saygısı yükseltme programı öncesi ve sonrası benlik saygısı puan ortalamaları verilmiştir. Göçle gelmeyen grubun müdahale

Tablo 2. Göçle Gelen ve Gelmeyen Ergenlerin Benlik Saygısını Etkileyen Faktörler

\begin{tabular}{|c|c|c|}
\hline Benlik saygısını etkileyen faktörler $(n=40)$ & Sayı & $\%$ \\
\hline \multicolumn{3}{|l|}{ Okul Başarısı } \\
\hline İyi & 25 & 67.5 \\
\hline Orta & 12 & 25.0 \\
\hline Kötü & 3 & 7.5 \\
\hline \multicolumn{3}{|l|}{ Okul yaşantısından } \\
\hline Memnun & 30 & 75.0 \\
\hline Memnun Değil & 10 & 25.0 \\
\hline \multicolumn{3}{|l|}{ Sağlığını algılama } \\
\hline İyi & 21 & 52.5 \\
\hline Orta & 19 & 47.5 \\
\hline \multicolumn{3}{|l|}{ Anne tutumu } \\
\hline Kararıma saygı duyar & 10 & 25.0 \\
\hline Kararları kendi verir & 28 & 70.0 \\
\hline İlgilenmez & 2 & 5.0 \\
\hline \multicolumn{3}{|l|}{ Baba Tutumu } \\
\hline Kararıma saygı duyar & 12 & 30.0 \\
\hline Kararları kendi verir & 23 & 57.5 \\
\hline İlgilenmez & 5 & 12.5 \\
\hline
\end{tabular}


Tablo 3a. Göçle Gelen ve Gelmeyen Gruplarda Benlik Saygısı Ön Test, Son Test ve İzlem Puan Ortalamalarının Dağılımı

\begin{tabular}{|l|c|c|c|}
\hline Benlik Saygısı Envanteri Puan Ortalamaları & \multicolumn{2}{|l|}{} \\
\hline Göç Durumu & $\begin{array}{c}\text { On Test Puan } \\
\text { Ortalaması }\end{array}$ & $\begin{array}{c}\text { Son Test } \\
\text { Puan } \\
\text { Ortalaması }\end{array}$ & $\begin{array}{c}\text { Izlem Puan } \\
\text { Ortalamaları }\end{array}$ \\
\hline Göçle Gelmeyen Grup (n=20) & $X(S S)$ & $X(S S)$ & $X(S S)$ \\
\hline Göçle Gelen Grup (n=20) & $243.20 \pm 1250$ & $246.85 \pm 17.97$ & $251.55 \pm 30.02$ \\
\hline Test İstatistiği (t) & $232.05 \pm 1801$ & $237.30 \pm 22.21$ & $253.05 \pm 35.26$ \\
\hline
\end{tabular}

Tablo 3b. Göçle Gelen Deney ve Kontrol Grubundaki Ergenlerde Benlik Saygısı Ön Test, Son Test ve İzlem Puan Ortalama Farklarının Dağılımı

\begin{tabular}{|c|c|c|}
\hline \multicolumn{3}{|l|}{ Benlik Saygısı Envanteri Puan Farkları } \\
\hline Göç Durumu & $\begin{array}{c}\text { Son Test/Ön Test Puan } \\
\text { Farkı Ortalaması }\end{array}$ & $\begin{array}{c}\text { İzlem/Ön Test Puan Farkı } \\
\text { Ortalaması }\end{array}$ \\
\hline & $\mathrm{X}(\mathrm{SS})$ & $\mathrm{X}(\mathrm{SS})$ \\
\hline Göçle Gelen Müdahale Grubu (n=10) & $13.40 \pm 17.34743$ & $36.90 \pm 33.95$ \\
\hline Göçle Gelen Kontrol Grubu (n=10) & $-2.50 \pm 32.98906$ & $5.10 \pm 17.89$ \\
\hline Test İstatistiği(t) & $\begin{array}{c}1.349 \\
p=0.199\end{array}$ & $\begin{array}{c}2.620 \\
p=0.021\end{array}$ \\
\hline
\end{tabular}

Tablo 3c. Göçle Gelmeyen Müdahale ve Kontrol Grubundaki Ergenlerde Benlik Saygısı Ön Test, Son Test ve İzlem Puan Ortalama Farklarının Dağılımı

\begin{tabular}{|l|c|c|}
\hline Benlik saygısı Envanteri Puan Farkları & $\begin{array}{c}\text { Son Test/Ön Test Puan } \\
\text { Farkı Ortalaması }\end{array}$ & $\begin{array}{c}\text { İzlem/Ön Test Puan Farkı } \\
\text { Ortalaması }\end{array}$ \\
\hline Göçle Gelmeyen Müdahale Grubu (n=10) & X( SS) & X( SS) \\
\hline Göçle Gelmeyen Kontrol Grubu (n=10) & $12.30 \pm 20.36$ & $25.90 \pm 33.64$ \\
\hline Test İstatistiği (t) & $-5.00 \pm 21.16$ & $-9.20 \pm 13.45$ \\
\hline p & 1.862 & 3.063 \\
\hline
\end{tabular}

Tablo3d. Göçle Gelen ve Gelmeyen Müdahale Gruplarındaki Ergenlerde Benlik saygısı Ön Test, Son Test ve İzlem Puan Ortalama Farklarının Dağılımı

\begin{tabular}{|l|c|c|}
\hline Benlik saygısı Envanteri Puan Farkları & $\begin{array}{c}\text { Son Test/Ön Test Puan } \\
\text { Farkı Ortalaması }\end{array}$ & $\begin{array}{c}\text { İzlem/Ön Test Puan Farkı } \\
\text { Ortalaması }\end{array}$ \\
\hline Gurumu & X (SS) & X (SS) \\
\hline Göçle Gelmeyen Müdahale Grubu (n=10) & $13.40 \pm 17.34$ & $36.90 \pm 33.95$ \\
\hline Test İstatistiği (t) & $12.30 \pm 20.36$ & $25.90 \pm 33.64$ \\
\hline p & -0.728 & -0.130 \\
\hline
\end{tabular}


öncesi benlik saygısı puan ortalaması $(243.20 \pm 12.5)$ göçle gelenlere göre $(232.05 \pm 18.01)$ sayısal olarak daha yüksek bulunmuştur. Benzer şekilde son test ve izlem benlik saygısı puan ortalamaları göçle gelmeyen grupta $(246.85 \pm 17.97 / 237.30 \pm 22.21)$, göçle gelen gruba (251.55 $\pm 30.02 / 253.05 \pm 35.26)$ göre sayısal olarak daha yüksek bulunmuştur. Bu sonuçlar arasında istatistiksel olarak anlamlı bir fark bulunamamıştır ( $\mathrm{p}>0.05)$.

Tablo 3b'de sadece göçle gelen müdahale ve kontrol gruplarının benlik saygısı puan farklarının ortalamalarının dağılımları verilmiştir. Benlik saygısı uygulanan grupta izlemdeki benlik saygısı puanı ile ön testteki benlik saygısı puanı arasındaki puan farkı ortalaması (36.90 \pm 33.95$)$, kontrol grubunun puan farkı ortalamasına $(5.10 \pm 17.89)$ göre daha yüksek ve istatistik olarak ortalamalar arası fark anlamlı bulunmuştur $(\mathrm{p}<0,05)$. Son test benlik saygısı puanı ile ön test benlik saygısı puan farkı ortalaması müdahale grubunda daha yüksek bulunmuştur ( $\mathrm{p}>0.05)$.

Tablo 3c'de göçle gelmeyen müdahale ve kontrol gruplarındaki ergenlerde benlik saygısı puan ortalamaları farkı dağılımları verilmiştir. Göçle gelmeyen müdahale grubunda

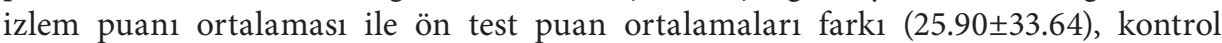
grubuna göre $(-9.20 \pm 13.45)$ daha yüksek bulunmuştur $(\mathrm{p}<0.05)$. Son test ve ön test puan ortalamaları farkı incelendiğinde ise son testte puan farkları sayısal olarak yüksek ancak istatistiksel olarak anlamlı bulunmamıştır ( $\mathrm{p}>0,05)$.

Tablo 3d incelendiğinde göçle gelmeyen müdahale ve göçle gelen müdahale grupları arasında son test ve ön test puan ortalaması farkları arasında istatistik açıdan anlamlı bir ilişki bulunmamıștır. Göçle gelmeyen müdahale grubunda izlem benlik saygısı puanı ve ön test benlik saygısı puan farkı (25.90土33.64) ile göçle gelen müdahale grubunda ki izlem ve ön test puan farkı ortalaması $(36.90 \pm 33.95)$ sayısal olarak yüksek bulunmuștur. $\mathrm{Bu}$ fark istatistiksel açıdan anlamı bulunamamıştır ( $\mathrm{p}>0,05)$.

Tablo 4'de araştırma kapsamına alınan kontrol ve müdahale gruplarının, grup içi benlik saygısı puanlarının analizi verilmiștir. Buna göre göçle gelmeyen müdahale grubunda müdahale sonrası benlik saygısı puanları, öncesi puanlarına göre artış göstermiş (242.60 $\pm 12.68 / 254.90 \pm 18.29 / 268.50 \pm 32.97)$ ve özellikle program sonrası izlemde benlik saygısı puanı, program sonrası son test ve ön test benlik saygısı puan ortalamalarına göre yüksek ve istatistiksel açıdan anlamlı bulunmuştur $(\mathrm{p}<0.05)$. Yine göçle gelmeyen kontrol grubunda benlik saygisı puan ortalamaları $(242.00 \pm 24.90 / 244.00 \pm 29.00 / 234.00 \pm 24.60)$ sayısal ve istatistiksel açıdan anlamlı bulunamamıștır. Göçle gelen müdahale grubunda

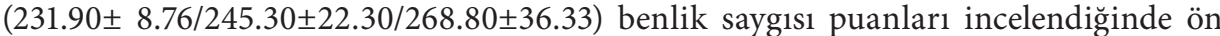
test puan ortalamalarına göre son test benlik saygısı puan ortalamaları ve izlem puan ortalamalarının giderek arttığını söyleyebiliriz. Yine bu artıș izlem ve ön test benlik saygısı puan ortalamaları arasında en yüksek düzeyde ve istatistiksel açıdan önemli bulunmuştur $(\mathrm{p}<0.05)$. Göçle gelen kontrol grubundaki ergenlerde ön test benlik saygısı ortanca puanı ile son test ve izlem benlik saygısı puanları arasında hem sayısal hem de istatistiksel olarak anlamlı bir artış görülmemiștir (Tablo 4).

\section{TARTIŞMA}

Göç bireyin sağlı̆̆ını etkileyen önemli faktörlerden biridir. İnsanlar göç ile çevrelerini tamamen değiştirdikleri için yeni çevrelerine uyum sağlayana kadar hem sosyal hem fizyolojik hem de ruhsal sağlıkları ile ilgili birçok sorunla karşı karşıya 
Tablo 4. Göçle Gelen ve Gelmeyen Müdahale ve Kontrol Gruplarının Benlik Saygısı Ön Test, Son Test ve İzlem Puan Ortalamalarının Dağılımı

\begin{tabular}{|c|c|c|c|c|}
\hline Göç Durumu & $\begin{array}{c}\text { Göçle Gelmeyen } \\
\text { Müdahale } \\
(n=10)\end{array}$ & $\begin{array}{c}\text { Göçle Gelmeyen } \\
\text { Kontrol } \\
(n=10)\end{array}$ & $\begin{array}{c}\text { Göçle Gelen } \\
\text { Müdahale } \\
(n=10)\end{array}$ & $\begin{array}{c}\text { Göçle Gelen } \\
\text { Kontrol } \\
(n=10)\end{array}$ \\
\hline $\begin{array}{l}\text { Benlik } \\
\text { Saygısı Puan } \\
\text { Ortalamaları }\end{array}$ & $\bar{X}_{ \pm \mathrm{sS}}$ & $\bar{X}_{ \pm \mathrm{SS}}$ & $\bar{X}_{ \pm \mathrm{sS}}$ & $\begin{array}{c}\bar{X}(\mathrm{SS}) \\
\text { Ortanca (EB-EK) }\end{array}$ \\
\hline $\begin{array}{l}\text { Ön Test Puan } \\
\text { Ortalaması }\end{array}$ & $242.60 \pm 12.68$ & $242.00 \pm 24.90$ & $231.90 \pm 8.76$ & $\begin{array}{c}225.00 \\
251.00-218.00\end{array}$ \\
\hline $\begin{array}{l}\text { Son Test Puan } \\
\text { Ortalaması }\end{array}$ & $254.90 \pm 18.29$ & $244.00 \pm 29.00$ & $245.30 \pm 22.30$ & $\begin{array}{c}234.00 \\
241.00-210.00\end{array}$ \\
\hline $\begin{array}{l}\text { İlem Puan } \\
\text { Ortalaması }\end{array}$ & $268.50 \pm 32.97$ & $234.00 \pm 24.60$ & $268.80 \pm 36.33$ & $\begin{array}{c}233.50 \\
258.00-215.00 \\
\end{array}$ \\
\hline \multicolumn{5}{|l|}{ Test İstatistiği } \\
\hline İzlem ve Ön Test & $7.446 p=0.001$ & \multirow{3}{*}{$\begin{array}{c}2.600 \\
p=0.273 \\
3.840 p=0.036 \\
2.190 p=0.293\end{array}$} & $6.029 p=0.001$ & \multirow{3}{*}{$\begin{array}{c}1.077 \\
P=0.584\end{array}$} \\
\hline $\begin{array}{l}\text { İzlem ve Son } \\
\text { Test }\end{array}$ & $4.866 p=0.008$ & & & \\
\hline $\begin{array}{l}\text { Son Test ve Ön } \\
\text { Test }\end{array}$ & $2.580 p=0.190$ & & & \\
\hline
\end{tabular}

kalabilirler ${ }^{2,3,16,17,31,33}$. Hovey $1996^{32}$ yılında yaptığ 1 bir çalışma da orta Amerika'dan ABD'ye yeni göç etmiş birinci kuşak gençler ile ABD'de doğmuş ailesi daha önce göç etmiş ikinci kuşak gençlerin depresyona yatkınlık ve intihar eğilimlerini incelemiş her iki grupta benzer oranda klinik düzeyde depresyon ve intihar fikirlerinin olduğunu tespit etmiştir. Yine diğer bir çalışmada ${ }^{31}$ ikinci kuşak Rusya'dan İsrail'e göçle gelen ergenlerde intihar oranı birinci kuşağa göre daha fazla belirlenmiştir. Bu durum göçle gelen bireylerin hem yeni geldikleri bölgede yaşadıkları sorunları hem de bu bölgede ne kadar süre yaşarlarsa yaşasınlar kendi aileleri ve sosyal çevreleri ile iletişim kurmakta sorunların uzun yıllar devam ettiğini düşündürmektedir. Çalışmalar uyum sorununu en çok yaşayan grupların ergenler olduğunu göstermektedir ${ }^{15-18}$. Ergenlik insanın yaşam döngüsünde büyümenin sonlandığı ve yetişkinliğe doğru adım atıldığı dönemdir. $\mathrm{Bu}$ dönem fiziksel, zihinsel, duygusal, sosyal değişimlerin yaşandığı bir zaman dilimidir ${ }^{34}$. Ergenlerle ilgili yapılan bir çalışma ${ }^{35}$ ergenlerin yarısından fazlasında benlik saygısının düşük olduğunu göstermektedir. Bu çalışma Roy'un uyum modelinde ${ }^{36}$ belirttiği olumlu benlik kavramını oluşturmada ergenler için özel bir çaba harcanması gerektiğini göstermektedir. Yine ergenlerde yapılan çalışmalar $\mathrm{da}^{24-26,33}$ benlik saygısını anne baba tutumunun, annenin işinin, gelir durumunun etkilediği belirlenmiştir. Bireyin kendini kanıtlaması ve bulunduğu çevreye kendini kabul ettirme çabaları ergen dönemde diğer dönemlere göre daha yoğundur. Bu dönemde yaşanan göç bu çabanın bir kat daha fazla olmasına neden olmaktadır.

Göç ile ilgili yapılan çalışmalarda ${ }^{15-18,33}$ göçle gelen grupta benlik saygısı düzeyi, gelmeyenlere göre düşük ve istatistiksel olarak anlamlı bulunmuştur. Bu çalışmada ise göçle gelen ve gelmeyen gruplar arasında benlik saygısı açısından müdahale öncesi anlamlı bir fark bulunmamıştır (Tablo 3a). Bu durumun sebebi olarak diğer çalışmalarda gruplar arası benzerlikler (anne-baba tutumu, sosyo-kültürel ve ekonomik durum) 
açısından araştırma gruplarında gruba alınma konusunda bir ölçüt olarak alınmamış, sadece cinsiyet konusunda benzerlik sağlanmış olması düşünülmektedir. Çalışmanın yapıldığ 1 bölgenin genel özeliği olarak bütün ailelerin düşük sosyokültürel ve düşük ekonomik özellik göstermeleri, göç ve göçle gelmeyen gruptaki benlik saygısı düzeyleri arasında istatistiksel açıdan bir fark olmamasının nedeni olabilir. Ayrıca bu durum bir ergenin göç dışında birçok faktörden etkilendiğini ve benzer ortamı paylaşan göçle gelmeyen ergenlerin de en az göçle gelen ergenler kadar desteklenmeleri gerektiğini düşündürmektedir. Bununla beraber bu durumun nedeni, Bolt ve Kempen'in ${ }^{37}$, Çağlar'ın ${ }^{38}$, Seifert' ${ }^{3}{ }^{39}$, değindikleri bir arada yaşama (consentration) kavramları ile açılanabilir. Bu yayınlarda, göçle gelen bireylerin kendi akraba ya da hemşerilerinin bulunduğu bölgelerde yaşamak istedikleri ya da kendi kültürlerine yakın bölgeleri tercih ettikleri ifade edilmiştir. Kuruüzüm'ün yaptığ 1 bir $^{40}$ çalışmada yurt dışında yaşayan Türk işçilerinin yarısından fazlasının Türkler'in yaşadıkları bölgede ikamet etmeleri de bu durumun bir örneğidir. Çalışmanın yapıldığı bölgede gözlemler ve resmi liderlerle görüşme sonucunda benzer şekilde ailelerin kendi akraba ve hemşerilerinin yaşadıkları yerlerde ikamet ettikleri belirlenmiştir.

Ergenler kendini geliştirme, kendilerini topluma kabul ettirme, bir gruba ait olma istekleri gibi bireyde stres artırıcı sorunlarla baş etmeye çalışırlar, göç sonrası uyum sorunları da bu stresi artırır. Yapılan bir çalıșmada ${ }^{41}$ stres düzeyi ile benlik saygısı arasında negatif bir ilișki bulunmuştur. Bu çalışmada da göçle gelen grupta benlik saygısının düşük bulunması hem çevre değişimine bağlı uyum problemleri hem de yüksek stres düzeyine işaret etmektedir. Ayrıca her ergen bu dönemde, ana babasından farklı değer yargılarına sahip olduğunu fark eder. Aile değer sisteminden farklı olarak davranışlarına yön vermeye ve kendine özgü yeni değerler geliştirmeye başlar. Arkadaş grubunun değer yargılarını benimseyen ergen ailesine kısmen veya tamamen ters düşmeye başlar ${ }^{42}$. Göçle gelen ailelerde ise çoğu ana baba, kültürlerini korumak adına geleneksel tutumlarını değiştirmedikleri için çocuklarıyla aralarında çatışmaların daha da artacağ söylenebilir ${ }^{43}$.

Tablo 3b'de göçle gelen ergenlerden müdahale ve kontrol gruplarında, son test, ön test ve izlem, benlik saygısı puan farkları ortalamaları analizleri verilmiştir. Bu fark müdahale grubunda kontrol grubuna göre sayısal olarak daha yüksek istatistiksel olarak da anlamlı bulunmuştur $(\mathrm{p}<0.05)$. Yapılan bir çalışmada benlik saygısı yükseltme programı uygulanan grupta, yapılmayanlara oranla benlik saygısı düzeyi yüksek bulunmuştur ${ }^{23}$ Yine Kuruüzüm'ün yaptığ 1 bir çalışmada ${ }^{40}$ yurt dışından Türkiye'ye kesin dönüş yapmış ailelerin ergen çocuklarının sosyal uyumlarına bakılmış ve Türkiye'de yaşayanlara oranla sosyal uyumlarını daha düşük bulmuştur. Kuruüzüm çalışması sonrasında göçle gelen çocuklarının uyumlarının artırılması amacı ile sosyal yönden desteklenmeleri gerektiğini belirtmiştir. Uygulanan benlik saygısı yükseltme programı, Roy'un uyum modelinde tarif ettiği gibi olumlu benlik kavramı geliştirme ve toplumun ergenden beklediği rolleri göstermesi bakımından ergeni desteklemektedir. Ergene bu programda toplumun kendinden beklediği roller ve ergenin kendini hangi rollerde ne düzeyde gördüğünü anlama ve kimsenin mükemmel olamayacağ yapılmıştır. Ayrıca ergenin kendindeki hoşlandığı ve hoşlanmadığı durumları fark etmesi sağlanmıştır. Bu durumların değiştirilebilir olduğu, hoşlanmadığ şeylerin değişmez olduğu durumlarda ise bu konu hakkında ki düşüncelerinin değişebileceğine ilişkin cesaretlendirilmişti ${ }^{22,44}$. Ayrıca Tablo $3 \mathrm{~b}$ ve $3 \mathrm{c}$ incelendiğinde benlik saygısı puan farkları ortalamalarının hem müdahale hem de kontrol gruplarında izlem yapılan 
6. Ayda, son test yapılan 3. Aya göre daha yüksek ve istatistiksel olarak anlamlı olduğu bulunmuştur $(\mathrm{p}<0,05)$. Bu durum benzer yapılan çalışmaların bir hatta iki yıllık bir süre izlem gerektirdiğini düşündürmektedir.

Göçle gelmeyen müdahale grubundaki ergenlerde ön test, son test ve izlem benlik saygısı puan farkı ortalamaları göçle gelmeyen kontrol grubuna göre daha yüksek ve istatistiksel açıdan anlamlı bulunmuștur ( $\mathrm{p}<0.05)$ (Tablo 3c). Bu sonuçlarla benlik saygısı yükseltme programının göçle gelen ve gelmeyen gruplarda benzer etki yarattığını söyleyebiliriz. Bu durum, iki grubun aile özelliklerinin ve benlik saygısını etkileyen faktörlerin homojen olmasından kaynaklanabilir. Yapılan birçok çalışmada göç gibi büyük bir çevre değişimi olmasa da ilgisiz anne baba tutumu, çok kardeşe sahip olma, gelir düzeyinin düşük olması gibi durumlardan ergenler etkilenmekte ve benlik saygıları düşmektedir ${ }^{24-26,33}$. Bu nedenle sadece göçle gelen ergenlerin değil, göçle gelmeyen ergenlerin de kişilik gelişimlerini sağlayacak ilerde daha sağlıklı bir yetişkin olmalarına olanak sağlayan bu tür programların uygulanmasının önemi büyüktür. Bu tür çalışmalar yapılarken ergen kadar ergenin ailesi ve okul yaşantısı da önemlidir. Ergenin çocukluk döneminden itibaren ailede anne-babanın çocuğa karşı tutum ve davranışları çocuğun gelecekteki yaşantısı açısından önemli olduğu kadar, çocuğa ailenin bir üyesi olduğu bilincini de aşılamakta ve topluma uyumunun temelini atmaktadır. Aynı zamanda ergen ailede bir birey olarak sosyal deneyimlerini edinmekte, tercihler yapmakta ve kararlarda etkin rol alarak karar vermeyi de öğrenmektedir ${ }^{41}$. Bu nedenle uygulanan programların gerçekçiliğini ve uygulanabilirliğini aileyle tartışarak yapmak uygulayıcıları daha gerçekçi sonuçlara götürecektir. Çünkü ergeni ne ailesinin yanında, ne de okulunda tek başına düșünebiliriz. Bu uygulamayı yapacak hemşire mutlaka ergenin ailesi ve okulda öğretmenleri ile işbirliği içinde olmalı ve özellikle rehber öğretmenlerle beraber çalışmalıdır.

Tablo 3d incelendiğinde göçle gelen ve gelmeyen müdahale gruplarında ergenlerin ön test, son test ve izlem benlik saygısı puan farkları ortalamaları incelendiğinde; göçle gelen müdahale grubunun göçle gelmeyen müdahale grubuna göre puan farkları ortalamalarının sayısal olarak daha yüksek olduğu ancak bu farkın istatistiksel olarak anlamlı olmadığ 1 görülmektedir $(\mathrm{p}>0.05)$. Bu durum benlik saygısı yükseltme programının göç grubunda benlik saygısını sayısal olarak daha fazla yükselttiğini düşündürmektedir. Göç hiçbir zaman basit anlamda bir yer değiştirme olarak görülmemelidir. Göç bir sosyoekonomik sistemden, bir kültürel örüntüden diğerine geçmektir. Ergenler göç sonrası kendilerini yeni ve eski kültür arasında seçim yapmaya zorunlu hissederler. Bu zor seçimlerse ergenlerde problemler (düşük benlik saygısı, depresyon, başarısızlık, davranış problemleri) gelişmesine sebep olabilir ${ }^{15-18}$. Ayrıca yapılan bir çalışmada okula giden göçle gelmiş ergenlerin, okula devam etmeyenlere göre, kültürlenme düzeyleri, benlik saygıları ve yaşam doyumları yüksek bulunmuştur. Yine bir çalışmada okula giden iç göç yaşamış çocukların sosyal uyumları, göçle gelmeyenlere göre daha düşük bulunmuștur. Bu çalıșmalarda göçle gelen çocukların okula gitmeleri, uyumlarını artıracak spor, müzik, tiyatro gibi faaliyetlere katılmaları gerekliliği ve bu çocukların uyumu için eğitim, sağlık ve sosyal hizmet kuruluşlarının eşgüdümlü çalışmalarının gereği vurgulanmıştır ${ }^{18,46}$. Çalışma da göçle gelen müdahale grubunda benlik saygısı puan farkının, göçle gelmeyen müdahale grubuna göre sayısal olarak yüksek bulunması, göçle gelmeyen ergenlerinde eğitim, sosyal ve sağlık alanlarında desteklenmeleri gerektiğini düşündürmektedir. Bunun yanı sıra sonucun 
istatistiksel olarak anlamlı olmaması göçün tek başına uyumda bir etken olmadığını, göçle gelinen bölgenin sosyo-ekonomik durumunun, anne baba eğitimlerinin çocuklarda uyumu etkilediğini bize düşündürmektedir. Bu nedenle sadece göçle gelen değil bütün ergenler da olumlu benlik kavramını geliştirmek, benlik saygılarını yükseltmek ergenlerin ilerde ki yaşamlarında daha sağlıklı ve psikolojik sorunlardan uzak olabileceklerini göstermektedir ${ }^{13,22}$.

Çalışmada müdahale ve kontrol grupları benlik saygısı programının benlik saygısına etkisi konusunda grup içi analizleri incelendiğinde (Tablo 4), müdahale gruplarında son test ve izlem benlik saygısı puan ortalamalarının özellikle, ön test benlik saygısı puan ortalamalarına göre yüksek olduğu bulunmuştur. Müdahale gruplarında ön test ve son test benlik saygısı puan ortalamalarının istatistiksel açıdan anlamlı olduğu görülmüştür $(\mathrm{p}<0.05)$. Tablo 4'de müdahale gruplarında son testte de izlemde de benlik saygısı puan ortalamasının yükseldiği ve özellikle izlemde bu yükselişin daha fazla olduğu görülmektedir $(\mathrm{p}<0.05)$. Bu durum uygulanan benlik saygısı programının etkinliğinin zamanla daha da artığını göstermektedir. Yapılan çalıșmalarda benzer olarak benlik saygısı yükseltme programı, benlik saygısını olumlu yönde etkilemiştir ${ }^{18,19}$. Benlik saygısı benlik kavramının bir göstergesidir. Olumlu benlik kavramının geliştiği durumlarda benlik saygısı da yüksektir. Olumlu benlik kavramı ise Roy'un uyum modeline göre bireyin yeni durumuna uyum sağladığını gösteren bir göstergedir. $\mathrm{Bu}$ nedenle göçle gelen ve gelmeyen ergenlerin olumlu benlik kavramlarını geliştirmek için bu tür uygulamaların faydalı olduğu ve uygulanan benlik saygısı yükseltme programının ${ }^{22}$ Roy'un kuramında yer verdiğ ${ }^{36}$ olumlu benlik kavramını geliștirmek için kullanışlı bir kaynak olduğu söylenebilir.

\section{SONUÇ ve ÖNERILER}

Göç'ün ergenlerin uyumlarını etkilediği, müdahale ve kontrol grubu arasında anlamlı bir farkın olmaması ve grupların olumsuz sosyo-ekonomik düzey, ilgisiz yada aşırı disiplinli anne baba tutumu, fazla kardeş sayısı, düşük anne baba eğitimi gibi konularda homojen olması nedeni ile bu konularda sıkıntılı olan ergenlerin de en az göçle gelen ergen kadar olumsuz etkilendiği ve benlik saygısını yükseltme programının hem göçle gelmiş hem de göçle gelememiş ergenlerin benlik saygısını anlamlı düzeyde yükselttiğini söyleyebiliriz.

$\mathrm{Bu}$ sonuçlar doğrultusunda;

- Göçle gelmiş farklı kültürlere sahip ergenlerin geldiği bölgedeki uyumlarını artırmak amacı ile yaşıtlarıyla beraber olabileceği ortamların oluşturulması ve benlik saygısını yükseltme gibi uygulamaların yapılması,

- Sadece göçle gelen değil, sosyo ekonomik anlamda düşük seviyede, anne baba tutumunun ilgisiz ya da kendiyle ilgili kararlarda ergene söz hakkı tanımayan, anne baba eğitimi düşük, kardeș sayısı fazla olan bölgelerde yaşayan ailelerin ergen çocuklarının da desteklenmesi,

- Benlik saygısı yükseltme programına benzer şekilde yapılan uygulamalarda etkinliğin değerlendirilmesi için en az 6 ay ile 1 yıllık bir sürenin geçmesi önerilebilir

- Çalışma farklı gruplarda tekrarlanabilir. İleri araştırmalar planlanabilir. 


\section{KAYNAKLAR}

1. Erten ZK, Zincir H, Özen B, Dinç S, Sevig Ü, F Özkan, Göçle Gelen Ailelerin Sağlıkla İlgili Bazı Davranış ve Görüşlerinin Saptanması, Hacettepe Üniversitesi Hemşirelik Fakültesi Dergisi, 2014;1(3):35-46.

2. Akan Y, Arlan İ. Göç Ekonomisi (Türkiye üzerine bir uygulama) (1. Baskı). Ekin Basım Yayın Dağıtım, Bursa, 2008:3-16.

3. Yalçın C. Göç Sosyolojisi(1. Baskı), Anı Yayıncılık, Ankara, 2004:11-22.

4. Fıchter J. Sosyoloji Nedir (7. Baskı), Çeviri Çelebi N, Anı Yayıncılık, Ankara, 2004: 181-192.

5. Çelik F, İç göçlerin itici ve çekici güçler iç göçlerin itici ve çekici güçler yaklaşımı ile analizi, Erciyes Üniversitesi İktisadi ve İdari Bilimler Fakültesi Dergisi, 2006:27,Temmuz-Aralık;149-170.

6. McEwen M, Wills E.M. Theoretical Basis for Nursing (2nd Ed), Lippicott Williams and Wilkins, United States, 2006:169-177.

7. Mc Mahon S D, Watts R J. Ethnic identity in urban African American youth: Exploring links with selfworth, aggression, and other psychosocial variables. Journal of Commuitty Psychology, 2002;30(4):411-431

8. İsbir G, Mete S. Hemşirelik bakımında model kullanımına bir örnek: bulantı kusma sorunu olan bir gebenin Roy uyum modeline göre incelenmesi. DEUHYO ED 2009; 2(2):75-86.

9. Figen SP, Mete S. Uyum modeli ve sosyal bilişsel öğrenme kuramının doğum öncesi eğitimde kullanımı. DEUHYO ED 2009;1 (1):57-68.

10. Roy, C. The Roy Adaptation Model (3rd ed), New Jersey Upper Saddle River: Pearson Prentice Hall Health, 2009:35-50.

11. İnanç B.Y, Yerlikaya E.E, Kişilik Kuramları, 2. Bölüm, Sigmund Freud,13. Baskı, Pegem Akademi, Ankara, 2017:11-39

12. İnanç B.Y, Yerlikaya E.E, Kişilik Kuramları, 2. Bölüm, Eric From,13. Baskı, Pegem Akademi, Ankara, 2017:111-129.

13. Öz F. Sağlık Alanında Temel Kavramlar (1. Basım), İmaj İç ve Dış Ticaret Aş, Ankara, 2004:83-127.

14. Çakmaklı K. Aile için sosyal hizmet (1. Basım). T.C. Başbakanlık Aile Araştırma Kurumu Başkanlığı Yayınları, İstanbul,1991:139-163.

15. Özen Ş, Antar S, Özbulut Ö, Altındağ A, Oto R. İç göç yaşayan bir grup lise öğrencisinde ruhsal belirti şiddetinin cinsiyet ile ilişkisi. Çocuk ve Ergen Ruh Sağlı̆̆ı Dergisi 2001;8(3):156-162.

16. Sır A, Bayram Y, Özkan M. Zorunlu iç göç yaşamış bir grupta travma sonrası stres bozukluğu üzerine bir ön çalışma. Türk Psikiyatri Dergisi, 1998; 9(3):173-180.

17. Aker T, Ayata B, Özeren M, Buran B, Bay A Zorunlu iç göç: Ruhsal ve toplumsal sonuçları, Anadolu Psikiyatri Dergisi, 2002; 3(2):97-103.

18. Gün Z, Bayraktar F. Türkiyede'ki İç Göçün ergenlerin uyumundaki rolü, Türk Psikiyatri Dergisi, 2008;19(2):167-176.

19. Zincir H, Yagmur F, Erten Kaya Z, Balci E, Elmalı F. The incidence of domestic violence, the causative factors and their effects on the family. Pak J Med Sci January-March 2010; 26 (1): 201-205.

20. Sullivan R, Gaffikin L, Lowry E. Editör Özvarış BÖ. Tıp Eğitimcileri İçin Program Geliştirme Rehberi(1. Basım), JHPIEGO, Ankara, 1999:48-68.

21. Yıldırım A, Şimşek H.Sosyal Bilimlerde Nitel Araştırma Yöntemleri (4.Basım). Tıpkı Basım, Ankara, 2004:103-124.

22. Kaya A, Saçkes M. Benlik Saygısı Geliştirme Programının 8. Sınıf Öğrencilerinin Benlik Saygısı Düzeylerine Etkisi, Deneysel Olarak Sınanmıș Grupla Psikolojik Danışma ve Rehberlik Programları (1Basım), Editörler Erkan S, Kaya A, Pegem Yayıncılık, Ankara, 2005:1-40. 
23. Çeçen A.R, Koçak, E. Deneysel bir çalışma: ilköğretim II. kademe öğrencilerine uygulanan benlik saygısı programının öğrencilerin benlik saygısı üzerindeki etkisi. Eğitim Araştırmaları, 2007;27:59-68.

24. Sezer Ö. Ergenlerin kendilik algılarının anne baba tutumları ve bazı faktörlerle ilişkisi, Yüzüncü Yıl Üniversitesi Eğitim Fakültesi Dergisi, 2010; 7(1):1-19.

25. Karadağ G, Güner İ, Çuhadar D, Uçan Ö. Gaziantep üniversitesi sağlık yüksekokulu hemşirelik öğrencilerinin benlik saygıları. Fırat Sağlık Hizmetleri Dergisi 2008;3(7) :30-42.

26. Baybek H, Yavuz Ş. Muğla üniversitesi öğrencilerinin benlik saygısının incelenmesi. Muğla Üniversitesi SBE Dergisi, 2005;14:73-95.

27. Güngör, A. (1989). Lise öğrencilerinin özsaygı düzeylerini etkileyen etmenler. Yayınlanmamış Doktora Tezi, Hacettepe Üniversitesi, Sosyal Bilimler Enstitüsü, Ankara.

28. Rosenberg M (1965) Society and the adolescent self-image. Princeton, NJ: Princeton University Press.

29. Coopersmith S. The antecedents of self-esteem. V.H Freeman Company, Sanfransisco, 1967.

30. Kaya, A ve Sackes, M. Benlik saygısı geliştirme programının ilköğretim 8.sınıf öğrencilerinin benlik saygısı düzeylerine etkisi. Türk Psikolojik Danışma ve Rehberlik Dergisi, 2004;3(21):49-56.

31. Ponizovski AM, Ritsner MR, Modal I. Suicidal ideation and suicide attempts among immigrant adolescents from the former Soviet Union to Israel. J Am Acad Child Adolesc Psychiatry, 1999;38:14331441.

32. Hovey JD, King CA . Acculturative stress, depression and suicidal ideation among immigrant and second generation Latino adolescents. J Am Acad Child Adolesc Psychiatry, 1996;35: 1183-1192.

33. Polat G. İç göçün çocuk ruh sağlığına etkisi ve sosyal hizmet müdahalesi. Toplum ve Sosyal Hizmet, 2007; 18(1):89-106

34. Adams, J.F. Ergenliği Anlamak (1.Basım). Çev. Onur B, İmge Kitabevi, Ankara, 1995:227-229.

35. Harter S. Identity and self development. In S. Feldman and G. Elliott (Eds.), At the threshold:The developing adolescent, Harvard University Pres, Cambridge,1990:352-387.

36. Roy, C. The Roy Adaptation Model (3rd ed), New Jersey Upper Saddle River: Pearson Prentice Hall Health, 2009:35-50.

37. Bolt, G. S. and Kempen, R. Segregation and Turks' housing conditions in middle-sized Dutch cities. New Community, 1997;23(3):363-384

38. Çağlar, A. German Turks in Berlin: social exclusion and strategies for social mobility. New Community 1995;23(3):309-323.

39. Seifert W. Occupational and social integration of immigrant groups inGermany. New Community,1996;22(3): 417-436.

40. Kuruüzüm A. Kesin Dönüş Yapan İşçi Çocuklarının Uyum Problemi Üzerine Bir Alan Araştırması. Akdeniz İ.İ.B.F. Dergisi, 2002;3:102-113

41. Nemeth PM, Penckofer S, Gulanick M, Friedrich BV, Bryant F. The Relationships Among Self-Esteem, Stress, Coping Eating Behavior, and Depressive. Research in Nursing \& Health, 2009;32, 96-109.

42. Oskay G. Değer yargıları yönünden ana-baba ergen çatışması. Hacettepe Üniversitesi Eğitim Fakültesi Dergisi,1990;5:221-244.

43. İnceoğlu D, Erkman F, Aytar Güler. Yurt dışından kesin dönüş yapan ana-babaların aile yaşamı ve çocuk yetiştirme tutumu açısından türkiye’ deki ana-babalarla karşılaştırılması. Ulusal Psikiyatri ve Nöroloji Kongresi, 1986;117-119.

44. Elllis A. Reflections on rational-emotive therapy. Journal of Consulting and Clinical Psychology, 1993;61(2):199- 201. 
45. Erbil N, Divan Z, Önder P. Ergenlerin benlik saygısına ailelerinin tutum ve davranışlarının etkisi, Aile ve Toplum dergisi, 2006;3(10):7-15

46. Uluocak PG. İç göç yaşamış ve yaşamamış çocukların okulda uyumu. Dokuz Eylül Üniversitesi Buca Eğitim Fakültesi Dergisi,2009;26:35-44. 